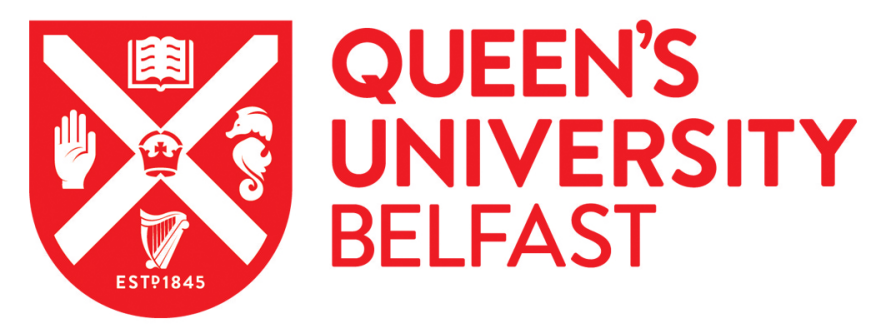

\title{
Impacts of groundwater drainage on peatland subsidence and its ecological implications on an Atlantic raised bog
}

Regan, S., Flynn, R., Gill, L., Naughton, O., \& Johnston, P. (2019). Impacts of groundwater drainage on peatland subsidence and its ecological implications on an Atlantic raised bog. Water Resources Research. https://doi.org/10.1029/2019WR024937

Published in:

Water Resources Research

Document Version:

Publisher's PDF, also known as Version of record

Queen's University Belfast - Research Portal:

Link to publication record in Queen's University Belfast Research Portal

Publisher rights

@2019. American Geophysical Union. All Rights Reserved. This work is made available online in accordance with the publisher's policies. Please refer to any applicable terms of use of the publisher.

\section{General rights}

Copyright for the publications made accessible via the Queen's University Belfast Research Portal is retained by the author(s) and / or other copyright owners and it is a condition of accessing these publications that users recognise and abide by the legal requirements associated with these rights.

Take down policy

The Research Portal is Queen's institutional repository that provides access to Queen's research output. Every effort has been made to ensure that content in the Research Portal does not infringe any person's rights, or applicable UK laws. If you discover content in the Research Portal that you believe breaches copyright or violates any law, please contact openaccess@qub.ac.uk. 


\section{Water Resources Research}

\author{
RESEARCH ARTICLE \\ 10.1029/2019WR024937 \\ Key Points: \\ - Quantification of the impact of \\ marginal drainage on peat \\ hydrogeological properties, \\ groundwater heads and surface \\ ground level \\ - Peat consolidation (>5\%) most \\ intense where it is underlain by \\ highly permeable ( $>10 \mathrm{~m} /$ day) \\ glacial till deposits \\ - New insights on the role of \\ groundwater as an environmental \\ supporting condition in \\ ombrotrophic raised bog ecosystems
}

Supporting Information:

- Supporting Information S1

Correspondence to:

S. Regan,

regans@tcd.ie

Citation:

Regan, S., Flynn, R., Gill, L., Naughton, O., \& Johnston, P. (2019). Impacts of groundwater drainage on peatland subsidence and its ecological implications on an Atlantic raised bog. Water Resources Research, 55. https://doi.org/10.1029/2019WR024937

Received 5 FEB 2019 Accepted 3 JUL 2019 Accepted article online 9 JUL 2019

(C)2019. American Geophysical Union. All Rights Reserved.

\section{Impacts of Groundwater Drainage on Peatland Subsidence and Its Ecological Implications on an Atlantic Raised Bog}

\author{
S. Regan ${ }^{1}\left(\mathbb{D}\right.$, R. Flynn $^{2}$, L. Gill ${ }^{1}$, O. Naughton ${ }^{3}$, and P. Johnston ${ }^{1}$ \\ ${ }^{1}$ Department of Civil, Structural and Environmental Engineering, University of Dublin Trinity College, Dublin, Ireland, \\ ${ }^{2}$ School of the Natural and Built Environment, Queen's University Belfast, Belfast, UK, ${ }^{3}$ Geological Survey Ireland, \\ Dublin, Ireland
}

\begin{abstract}
Field data of topography, water levels, and peat hydraulic conductivity collected over a 28-year period have revealed the impacts of marginal drainage on uncut raised bog ecohydrology and its peat properties. Drainage of the regional groundwater body has induced changes in the hydraulic properties of deep peat, with peat compression decreasing hydraulic conductivity and storativity while simultaneously introducing localized secondary porosity and effective storage. Where peat has increased in hydraulic conductivity, there is a corresponding decline in vertical hydraulic gradients and significant localized increases in recharge to the underlying substrate. Repeated topographic surveys show intense localized areas of peat consolidation ( $>5 \%$ ) where it is underlain by highly permeable ( $>10 \mathrm{~m} /$ day) glacial till deposits. More widely, continued subsidence (4-6 mm/year) of the bog surface has been measured over $900 \mathrm{~m}$ from the bog margin, resulting in the progressive loss of approximately $40 \%$ of actively growing raised bog since 1991. This loss has thus been shown to be attributable to changes in the underlying groundwater head due to deep-cut drainage, rather than near-surface peatland drainage. However, although reinstating regional hydrostatic pressures in order to restore this ombrotrophic peatland may control the rapid drainage through preferential flow pathways, this may not eliminate the ecological impacts resulting from changed surface morphology arising from subsidence. Hence, this longitudinal study provides new insights into the role that aquifer systems and groundwater bodies play in maintaining hydrogeological processes in ombrotrophic peatland systems, while highlighting the difficulty in ecological restoration where regional groundwater dependencies are significant.
\end{abstract}

\section{Introduction}

Peatlands are ecosystems of global significance; they play a key role in preserving global biodiversity and represent some of the largest natural terrestrial reservoirs of carbon (Leifeld \& Menichetti, 2018; Yu et al., 2011). The capacity of a peatland to actively sequester carbon (C) is dependent on maintaining physiographic and climatic conditions that favor water retention and peat accumulation (Fraser et al., 2001; Price, 2003; Roulet, 2000). However, exploitation has damaged their ecohydrological functioning and greatly diminished their global distribution, transforming them from long-term $\mathrm{C}$ sinks into sources due to alterations in hydrology (Joosten, 2009; Leifeld \& Menichetti, 2018; Young et al., 2017). This is particularly the case for raised bogs in Western Europe, which are now considered to be rare and are priority habitats for protection. Hydrological management is key to maintaining and/or restoring the peat-accumulating plant communities that give rise to the peatland $\mathrm{C}$ sink function, in addition to other valuable peatland ecosystem services such as regulation of water flows and biodiversity.

Ombrotrophic peatland ecology is dominated by bryophytes from the genus Sphagnum (Robroek et al., 2009; Van Breemen, 1995), whose stability is dependent on the dynamics of the water table relative to the ground level. In raised bogs, persistently high water tables $(<0.15-\mathrm{m}$ depth) are maintained when there is (a) a small topographic gradient limiting lateral flows and favoring increased recharge to groundwater (Oosterwoud et al., 2017; Van der Schaaf \& Streefkerk, 2002); (b) a sufficient build-up of poorly humified organic materials to provide storativity in the upper peat layer (Ingram, 1983; Waddington et al., 2010); and (c) minimal downward infiltration/seepage and fluid flow at depth (Belyea \& Clymo, 2001; Morris et al., 2015; Quinton et al., 2008). Water flow and storage processes in peatlands are thus strongly controlled by the hydrogeological properties of peat (Price, 2003) and particularly the hydraulic conductivity $(K)$ profile, which controls the rate of subsurface drainage (Beckwith et al., 2003; Quinton et al., 2008). While the $K$ of saturated peat is 
highly variable, it generally decreases exponentially with depth, from high values $(<10 \mathrm{~m} /$ day $)$ close to the surface to low values at depth $\left(<10^{-3} \mathrm{~m}\right.$ /day; Letts et al., 2000; Quinton et al., 2008). However, evidence suggests that deeper peat can have permeablities as high as near-surface peat (Baird et al., 2017), and interconnected macropores at depth can act as significant flow pathways (Holden \& Burt, 2003; Quinton et al., 2009; Rossi et al., 2012; Siegel et al., 1995). Accordingly, hydraulic conductivity in peat is scale dependent, and water flow through peat may be more rapid than is generally recognized. In some cases, where hydraulic connection is strong, water tables may effectively be controlled by the hydrogeological conditions in an underlying aquifer (Devito et al., 1997).

Peat is a characteristically deformable medium (Hobbs, 1986) and undergoes subsidence when drained due, primarily, to consolidation and organic matter oxidation (Schlotzhauer \& Price, 1999; Wösten et al., 1997; Zanello et al., 2011). Consolidation results from a reduction in water content, which is reflected by an increase in organic matter content and a corresponding decline in $K$ (Moore et al., 2015; Schlotzhauer \& Price, 1999). This can result in a negative feedback in a peatland's water balance, limiting downward water loss. However, it has also been documented that deep drainage systems in areas surrounding undisturbed peatlands can increase downward seepage losses due to changes in water pressure and hydraulic gradients caused by external activities (Kværner \& Snilsberg, 2011; Price, 1996; Schouwenaars, 1993; Whittington \& Price, 2012). In these situations, peat may deform and its properties change. Macropores are known to occur in peat (Liu et al., 2016) and can develop into cracks and fissures, resulting in reduced resistance to flow and an increase in seepage losses to deposits underlying the peat (Schouwenaars, 1993).

The ecohydrology of a bog system relies on the maintenance of high water levels in the peat. The "groundwater" found in peat is generally conceptualized as being isolated from "groundwater" in the deeper groundwater body or regional aquifer system. However, this hydrological separation does not apply where peat develops directly on more permeable materials such as gravels and karsified limestone. Under these circumstances hydraulic gradients acting between the wetland and substrate materials can be a determinant in peatland development. This is particularly relevant for low-lying peatlands, such as fen-peat environments, where groundwater exfiltration as point discharges/preferential flows through low hydraulic conductivity peat matrices have been shown to maintain peatland groundwater levels (e.g., Johansen et al., 2011; Lowry et al., 2009; Rossi et al., 2012; Siegel \& Glaser, 1987). Deeper groundwater can also prove critical in raised bogs underlain by permeable inorganic deposits, with reversals in hydraulic gradient demonstrated to maintain groundwater levels in prolonged drought periods (Glaser et al., 1997; Reeve et al., 2000; Reeve et al., 2006; Siegel et al., 1995). However, the role regional groundwater plays in supporting piezometric heads in peat and overlying water tables remains poorly understood. Understanding this role has implications for conservation management and the restoration of degraded peatlands due to the potential for downward water losses to disrupt the ecohydrological balance. Peatland management thereby needs to consider the significance of the hydraulic connectivity between the peatland complex and groundwater body or regional aquifer system in maintaining piezometric heads (e.g., Auterives et al., 2011; Quillet et al., 2017; Rossi et al., 2012).

Spatially and temporally detailed information on topography, water levels, and peat hydraulic conductivity properties is rarely reported in peatland hydrology research. In this study, a long-term record (28 years) from a raised bog modified by marginal drainage brings new insights into peatland hydrogeological and subsidence processes. This paper reports on long-term research and examines (i) the impact of groundwater drainage on the hydrogeological properties of peat and subsidence (with consequential impact on ecology) and (ii) the role of regional groundwater pressure in supporting the water table in ombrotrophic peatlands.

\section{Site Description}

\subsection{Study Area}

This study was carried out at Clara Bog, a lowland raised bog site located in the Irish midlands $\left(53^{\circ} 19^{\prime} \mathrm{N}\right.$, $7^{\circ} 37^{\prime} \mathrm{W}$; Figure 1). The area experiences a temperate Atlantic climate with a mean annual (1981-2010) temperature and rainfall of $9.6^{\circ} \mathrm{C}$ and $883 \mathrm{~mm}$, respectively (Walsh, 2012). Clara is one of the largest raised bogs in Ireland with $>440$ ha of uncut bog supporting approximately $>100$ ha of peat-forming vegetation (NPWS, 2016), also known as active raised bog (ARB). The site is designated as a special area of conservation under the European Union Habitats Directive (Council of the European Communities, 1992) and a Ramsar 

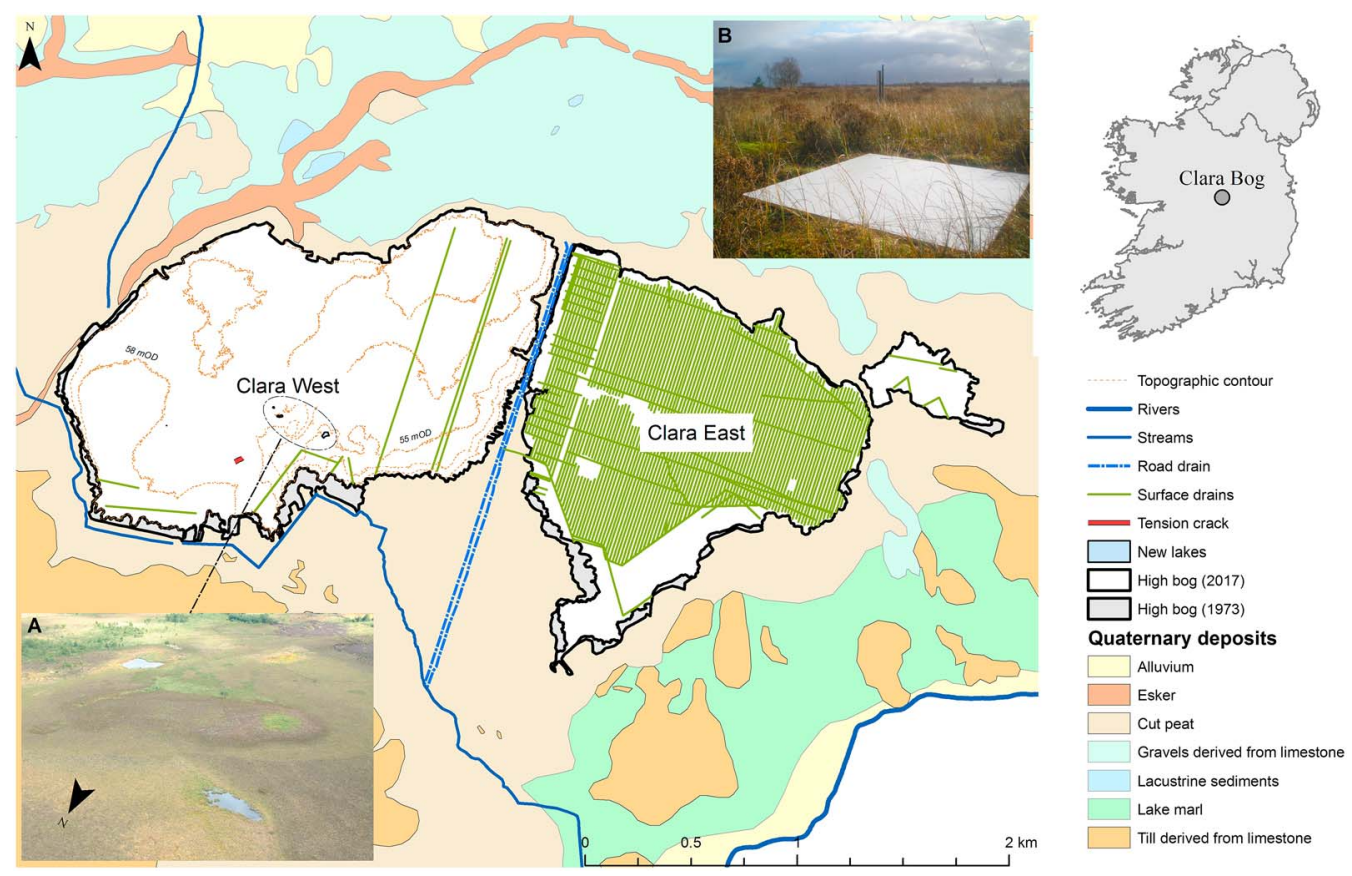

Figure 1. Map showing the location of Clara Bog, high bog boundaries, drainage features and quaternary deposits (Geological Survey of Ireland). Also shown is (a) aerial photograph of recently formed lake features and (b) a marker board used in LiDAR survey ground control.

wetland of international importance (Ramsar, 1971). Ireland has approximately $60 \%$ of the remaining raised bog habitat in Western Europe (NPWS, 2017), meaning the protection of sites like Clara is of international significance.

The bog complex is divided into two separate units, Clara West (240 ha) and Clara East (202 ha), divided by a $>200$-year old road (Figure 1). A dense network of surface drains was cut into Clara East in the early 1980s and was subsequently blocked in 1996. In contrast, Clara West is considered relatively intact, with the exception of two drains parallel to the bog road and another adjacent to the southern margin (also blocked in 1996). Local peat extraction between 1973 and 2017 has reduced the natural bog area at Clara West and Clara East by approximately $4 \%$ and $5 \%$, respectively, with losses concentrated at the southern boundaries. Drain blocking on Clara East has locally restored ARB; however, despite little surface drainage, Clara West has undergone significant morphological changes, such as the formation of lakes and tension cracks (Figure 1), with substantial losses in ARB (>40\%) recorded between 1991 and 2017 (NPWS, 2017). This current study focuses on Clara West, with findings compared to a previous hydrological study carried out on the bog between 1991 and 1993 (Van der Schaaf, 1999; Van der Schaaf \& Streefkerk, 2002).

\subsection{Hydrogeological Setting}

The bog is bounded by an esker and gravel complex on its northern side and by finer gravel carbonate-rich till deposits on its southern side (Figure 1). Boreholes drilled in the area show that these deposits overlie Mississippian Waulsortian Limestone bedrock, a moderately productive aquifer with groundwater flow confined to fractures and faults within the bedrock matrix. Till deposits underlie a substantial proportion of the bog (ca. 40\%; Figure 2). Till thickness ranges from 4 to $6 \mathrm{~m}$ adjacent to the bog margins and cutover areas, to between 8 and $10 \mathrm{~m}$ closer to the central area of the bog; depth to bedrock is $\sim 20 \mathrm{~m}$ below ground near the southern margin to $\sim 14 \mathrm{~m}$ at a ridge near the center of the bog. The till is composed of a clay-silt and sand based matrix and generally becomes more gravel rich with depth. Shallow peat depths $(<3 \mathrm{~m})$ are associated with areas where the till underlies the peat as a mound in the south-central area of the site. Deep peat basins $(8-10 \mathrm{~m})$ occur northwest and northeast of this ridge and are underlain by fine-grained laminated lacustrine clay (LC), which ranges in thickness between 0.2 and $>4.0 \mathrm{~m}$. Thin $(<0.5 \mathrm{~m})$ calcareous marl deposits overlie the LC in the southeastern area of the bog. Sand lenses, consisting of fine to coarse grained sand particles in a 


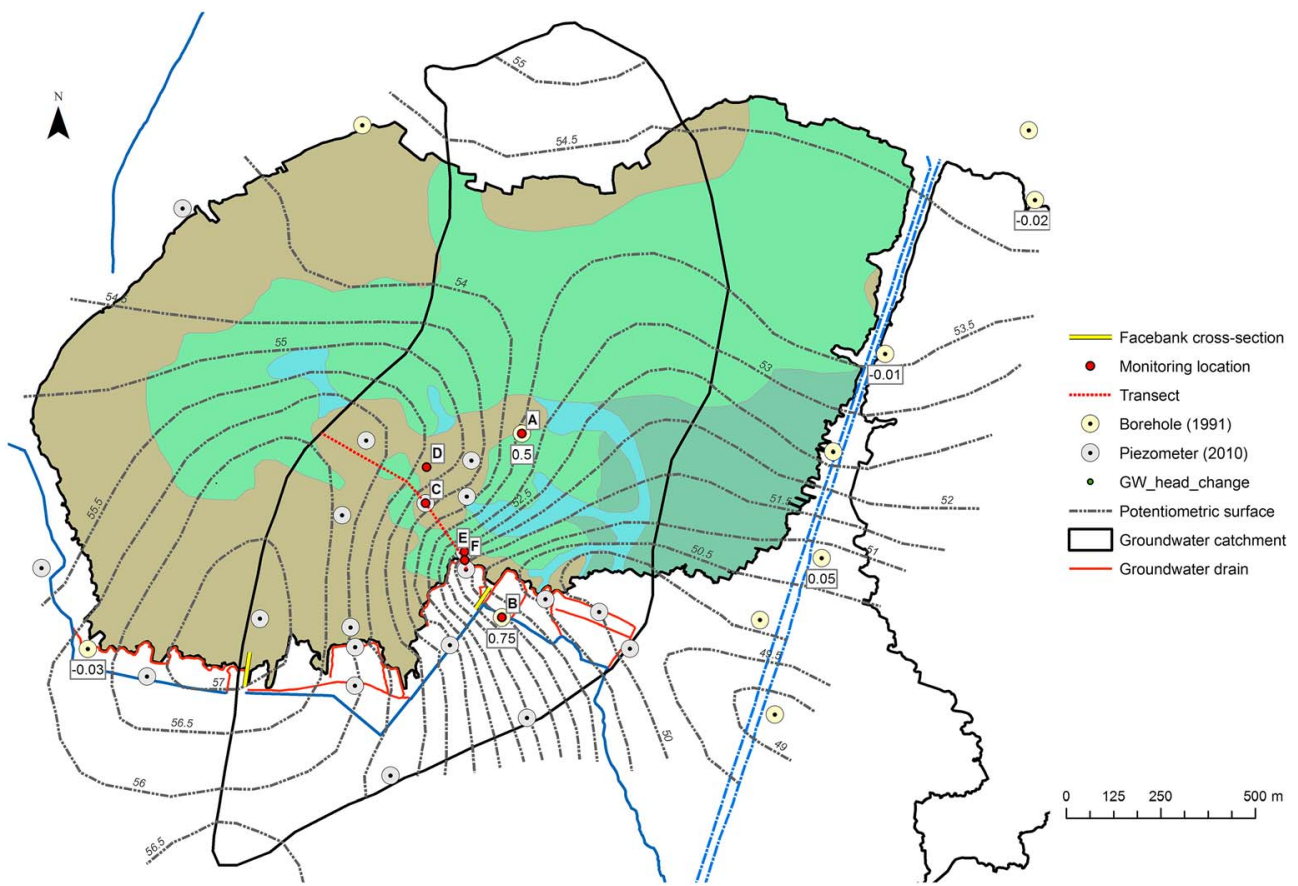

Figure 2. Location of monitoring stations in the till groundwater body, delineated potentiometric surface, and regional groundwater catchment (2010-2012). Note. A-B and C are boreholes installed in 1991 and 2010, respectively; D and E are locations used for autocorrelation analysis; and $\mathrm{F}$ is a piezometer nest located in a groundwater-fed drain. Seasonal potentiometric surface and regional groundwater catchment are included in the supporting information as Figures S2 and S3.

layer less than $20 \mathrm{~cm}$ thick, occur locally in the western and eastern regions of the bog. Geological maps are included in Figure S1 (supporting information).

\section{Materials and Methods}

\subsection{Field and Airborne LiDAR Topographic Survey}

A manual topographic survey (using a "Total Station") of ground level elevation was carried out across the bog surface in 1991 using a 100-m grid encompassing 238 points on the natural bog (Schouten, 2002; Figure S2). This was repeated in 2002 and on selected parts of the grid with an additional 610 points at an increased density, on a $25-\mathrm{m}$ grid. Topographic raster surfaces at $10-\mathrm{m}$ resolution were generated using the natural neighbor interpolation method in ArcGIS version 10.3. Airborne Light Detection and Ranging (LiDAR) surveys were carried out in December 2008, February 2012, and June 2017, by Terra-Imaging Ltd, Ordnance Survey Ireland, and Bluesky Ltd, respectively. LiDAR data were provided in the form of a high-resolution digital terrain model at 1-m grid resolution. The 2008 and 2017 surveys were calibrated using field measured Trimble R6 Differential Global Positioning System (DGPS) data from reflective $1.5-\mathrm{m}^{2}$ marker boards in 10 contrasting areas across the peatland surface (Figure 1). The root mean square error of the DGPS and LiDAR surveys were determined to be \pm 0.014 and $\pm 0.02 \mathrm{~m}$, respectively, giving a combined accuracy of $0.034 \mathrm{~m}$. The 1-m digital terrain models were smoothed to 10-m grid cells for comparison with the 1991 and 2002 interpolated raster surfaces. Peat thickness and elevation of the underlying mineral deposit maps were also interpolated to $10-\mathrm{m}$ grid cells using the natural neighbor interpolation method in order to calculate changes in peat volume (i.e., strain-measures change in peat thickness with respect to the initial thickness) over time (Figure S1, supporting information).

\subsection{Hydrology}

Water levels in peat and underlying till substrate were measured over two study periods; between 1991--993 (Van der Schaaf, 1999) and 2010-present (current study). Eleven regional monitoring boreholes in till were installed in 1991, and a further 20 piezometers were installed between 2010 and 2012 (Figure 2). Thirty-four 
piezometers nests, measuring water table and piezometric head at the base and midsection of the peat column, were installed between 1991 and 1993, with a further 32, including eight installed in drains, between 2002 and 2012 (Figure 3). All peat piezometers are 19-33-mm diameter PVC tubes with 0.35-m screened tips. Piezometers in mineral subsoil are 25-50-mm diameter galvanized steel pipes with $1.0-\mathrm{m}$ screened tips; open-screened PVC tubes were used for water table. All installations and peat coring locations were leveled using a total station and DGPS pre-2008 and post-2008, respectively. Biweekly manual water level measurements were recorded across the monitoring network during both analysis periods (1991-1993 and 2010-2012). Mean values of piezometric head were used to map potentiometric surfaces (2010-2012) and delineate catchment maps (Figures 2 and 3).

Continuous hourly water level (piezometric head) measurements were recorded at five piezometers between 2012 and 2018 and three phreatic tubes between 2015 and 2017. Schlumberger Diver@ loggers (estimated accuracy of \pm 0.5 - and 0.2 -cm resolution), compensated with a Baro-Diver recording local atmospheric pressure, were used for peizometric head measurement, and OTT $`$ Orpheus Mini vented-pressure instruments (estimated accuracy of $1 \mathrm{~mm}$ ) were used for phreatic water level. These data were used to record the time series of (1) piezometric head in till deposits ("regional groundwater") inside and outside of the uncut bog; (2) hydraulic gradient between stage and piezometric head at a groundwater-fed drain bordering the bog; and (3) differences in water table and piezometric head at the base of peat in an area of peat supporting $\mathrm{ARB}$ and where peat is damaged (fractured) and unable to support ARB. The temporal differences in the inertia or memory effect of water level signal were quantified using the autocorrelation function, $r(k)$, given by the following:

$$
\mathrm{r}_{\mathrm{xx}}(\mathrm{k})=\frac{1}{(\mathrm{n}-\mathrm{k}) \sigma^{2}} \sum_{\mathrm{t}=1}^{\mathrm{n}-\mathrm{k}}\left(\mathrm{x}_{\mathrm{t}}-\overline{\mathrm{x}}\right)\left(\mathrm{x}_{\mathrm{t}+\mathrm{k}}-\overline{\mathrm{x}}\right)
$$

where $k$ is the time lag, $n$ is the length of the time series, $x$ is a single event, and $\bar{x}$ is the mean of the events (Box et al., 2015). The memory effect was quantified using the decorrelation lag time, defined as the lag at which the autocorrelation function has fallen to a level below which the memory effect is adjudged indistinguishable from noise, and is typically taken as 0.2 (Padilla \& Pulido-Bosch, 1995; Box et al., 2015). A correlation level of 0.2 was used in this study.

\subsection{Drainage and Groundwater Interaction}

The drains on the southern margin of the natural bog were mapped and leveled using DGPS. A number of cores were also taken to determine peat thickness and underlying substrate lithology. To detect the origin of water in drainage features, electrical conductivity (EC) was utilized as an environmental tracer to distinguish between groundwater originating from the calcareous till and limestone deposits (which are relatively high in calcium and bicarbonate ions) and rainwater and surface runoff from the bog (which are considerably lower in ionic intensity, with chloride and sodium being the main ion constituents). Thus, the contrasts in EC are sufficiently large to identify whether the drains are gaining or losing groundwater. EC was measured at multiple points along all drainage features in the area south of the natural bog and also from a number of piezometers located in peat and till deposits. Drains that are considered to be "groundwaterfed" are shown in Figure 2. A piezometer nest, measuring stage and piezometric head at the base of peat and at the base of till, was installed at a location with continuous groundwater input to determine temporal differences in the vertical hydraulic gradient of local groundwater flow. The in-channel exchange of groundwater was further assessed by measuring EC continuously with a YSI Exo@ Sonde (accuracy $\pm 0.5 \%$ ), enabling measurement of the relative contributions of groundwater and surface water flow from the natural bog during runoff generation.

\subsection{Hydraulic Conductivity}

Field-based rising head piezometer tests were used to determine horizontal hydraulic conductivity using Hvorslev's (1951) method in 1991-1993 and 2010-2012. This method is based on Darcy flow and assumes that the compressibility of the medium is negligible and $K$ is constant. While this assumption is problematic in a compressible medium such as peat, the application of the model is the most commonly utilized field technique for measuring $K$ (e.g., Baird et al., 2004; Baird et al., 2017; Reeve et al., 2000). Measurements were carried out in piezometers installed to the midsection of the peat profile (mean depth $4.5 \mathrm{~m}$ ), composed of 


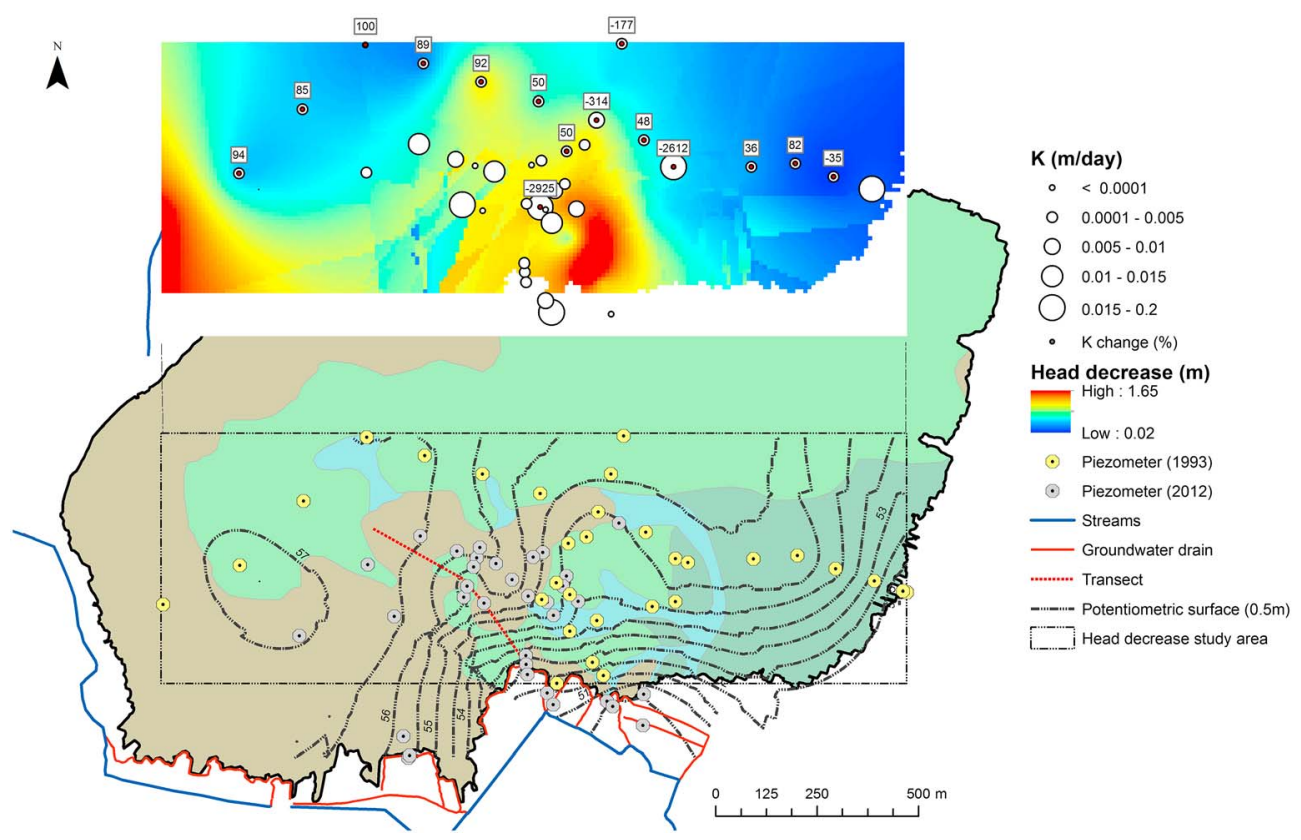

Figure 3. Location of piezometers in peat, potentiometric surface at the base of peat (2010-2012), variation in hydraulic conductivity, and decrease in mean head between1991-1993 and 2010-2012. K change refers to measured changes in $K$ between 1991-1993 and 2010-2012 at the same piezometer location.

humified Sphagnum peat with a fibrous structure, and at the base of the peat profile (mean depth $7.5 \mathrm{~m}$ ), composed of fen peat with an increased degree of humification (based on peat coring). In total, tests were carried out at 23 and 46 piezometers in the midsection and base of peat profiles, respectively (Figure 3), and a further 10 measurements in cut peat. Slug tests in peat piezometers were controlled in order to contain water level decreases within $10 \mathrm{~cm}$ of static water level. Log-linear rates of water level recovery were observed in the majority of tests, indicating steady-state conditions and minimal alterations of effective stresses following water extraction. Of these locations, $K$ measurements were carried out at 16 piezometers at the base of the peat profile in the 1991-1993 period (Van der Schaaf, 1999), deploying the same methodology, thereby permitting a comparison of $K$ properties before and after drainage. The Hvorslev method was also used to estimate $K$ from 16 piezometers in till, but with greater levels of static level drawdown.

\section{Results}

\subsection{Subsidence}

The difference in ground surface elevation between 1991 and 2017 at Clara West is shown in Figure 4a. Ground level declines are greatest in the south-central area of the bog, adjacent to a groundwater-fed drain, with levels $>1.0 \mathrm{~m}$ measured $>170 \mathrm{~m}$ from the bog margin, equating to a peat thickness reduction of $>20 \%$ (Figure 4b). Level declines of 0.5, 0.2, and $0.1 \mathrm{~m}$ are measured within 450, 650, and $900 \mathrm{~m}$ from the southern boundary, respectively, equating to peat thickness losses of 1-10\%. Ground level declines in the western, eastern, and northern areas of the bog are localized and do not propagate to the same extent inward. The decline in ground level is considered to be subsidence (peat consolidation), and an overall loss in peat mass between 1991 and 2017 is estimated as $421,771 \mathrm{~m}^{3}$. In the period 2008-2017, ground level declines $>0.1 \mathrm{~m}$ are concentrated around the central and northern regions and appear to have stabilized in the southern region of the bog (Figure 4c). In contrast to Clara West, there is no evidence of groundwater drainage at Clara East. The majority of the natural bog surface in Clara East has risen by a mean of approximately $0.014 \pm 0.2 \mathrm{~m}$ (Figure 4d) between 1991 and 2017. Moderate increases in ground level are attributed to the extensive surface drain blocking that took place in the early 1990s, whereas declines are likely a result of lowered summer ground levels in areas of ARB and drainage impacts closer the bog margin. 
A

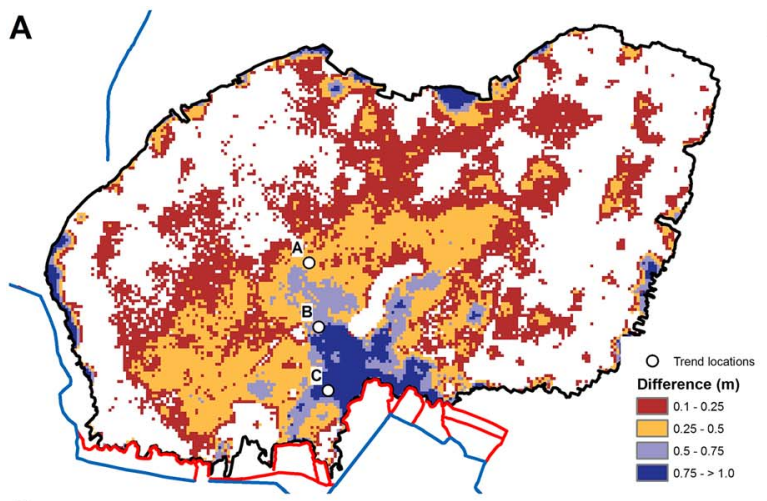

C

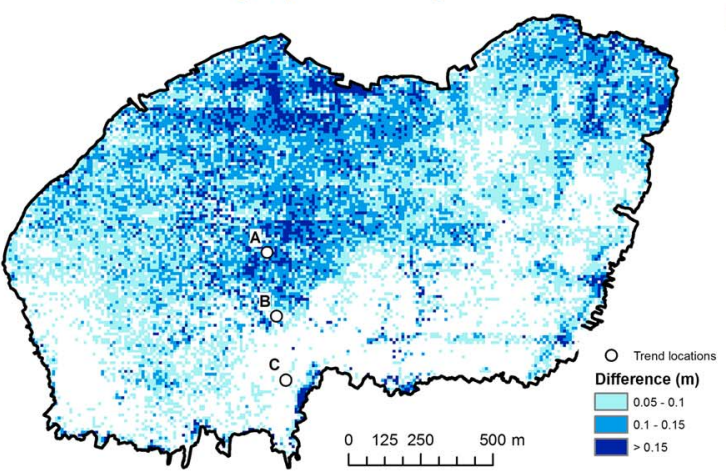

B

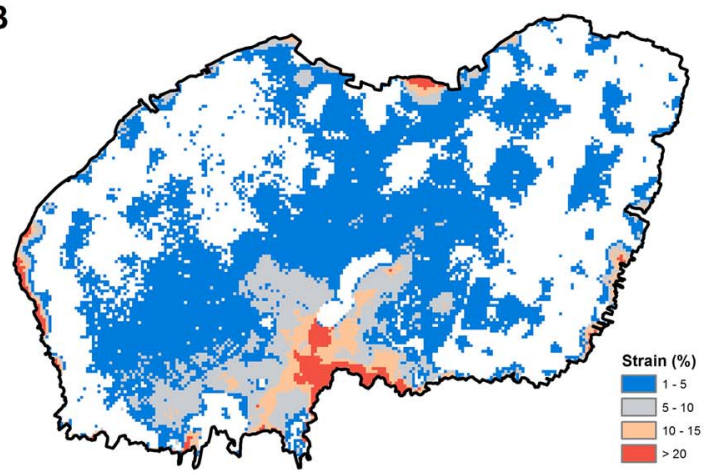

D

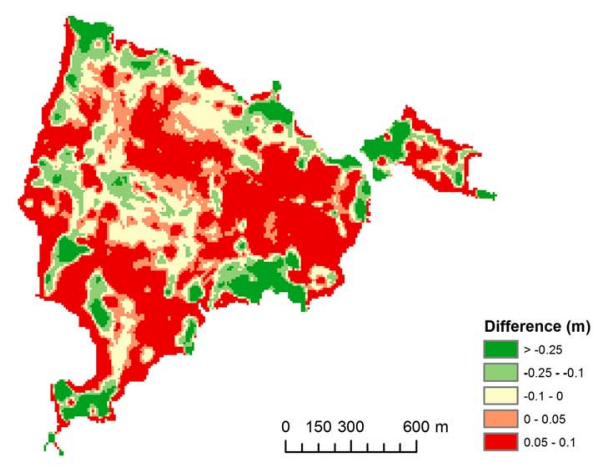

Figure 4. (a) Decline in ground surface at Clara West (1991-2017); (b) decrease in peat thickness (\% strain); (c) decline in ground surface at Clara West (2008-2017); (d) difference in ground surface elevation at Clara East (1991-2017). Note. Error $\pm 0.034 \mathrm{~m}$; ground level time series of monitoring points A, B, and C is shown in Figure S4 (supporting information).

Rates of subsidence (Table 1) have been calculated using time series measurements of ground level from each of the fixed positions on the 100-m grid. The mean rate in the 1991-2002 period is $21.8 \pm 19.8$ $\mathrm{mm} /$ year, decreasing to between 4 and $6( \pm 4-6) \mathrm{mm}$.year in the post measurement periods. Where peat overlies till, the mean rate was $28.4 \pm 23.2 \mathrm{~mm} /$ year, compared to $15.5 \pm 14.7 \mathrm{~mm} /$ year where the underlying subsoil is LC. Rates reduce significantly in the period post 2008 to mean rates of $\sim 6( \pm 4) \mathrm{mm} /$ year in both

Table 1

Estimated Mean and Standard Deviation Subsidence Rate in 1991-2017 in Peat Overlying Till and Lacustrine Clay

\begin{tabular}{lccc}
\hline Year & All & Till & LC \\
\hline Rate $(\mathrm{mm} /$ year) & & & \\
$1991-2002$ & $21.8(19.8)$ & $28.4(23.2)$ & $15.5(14.7)$ \\
$2002-2008$ & $4.4(5.4)$ & $8.5(5.9)$ & $2.6(3.9)$ \\
$2008-2012$ & $4.2(3.0)$ & $4.3(2.8)$ & $5.4(2.4)$ \\
$2012-2017$ & $6.1(3.8)$ & $6.1(4.0)$ & $6.3(3.9)$ \\
Strain $(\%)$ & & & \\
$1991-2002$ & $11.5(84.1)$ & $23.5(160.5)$ & $2.0(2.2)$ \\
$2002-2008$ & $1.5(10.9)$ & $3.2(2.7)$ & $0.1(0.5)$ \\
$2008-2012$ & $0.2(0.4)$ & $0.2(0.01)$ & $0.2(0.4)$ \\
$2012-2017$ & $0.4(0.5)$ & $0.4(0.01)$ & $0.3(0.5)$ \\
Rate $\left(\mathrm{mm} \cdot\right.$ year $\left.^{-1} \cdot \mathrm{m}^{-1}\right)$ & & \\
$1991-2002$ & $3.09(3.29)$ & $4.33(15.7)$ & $1.95(2.18)$ \\
$2002-2008$ & $0.66(1.32)$ & $1.22(2.47)$ & $0.31(0.84)$ \\
$2008-2012$ & $0.5(1.09)$ & $0.57(1.16)$ & $0.61(0.89)$ \\
$2012-17$ & $0.73(1.02)$ & $0.82(1.25)$ & $0.69(0.97)$ \\
\hline
\end{tabular}

Note. Measurements based on where a decrease of $>0.1 \mathrm{~m}$ is recorded between 1991 and 2017 (106 points). LC is lacustrine clay. till and LC areas. The large standard deviations are a consequence of (1) the large spatial variability in subsidence rates, as shown in Figures 4 and S4, due to underlying geological conditions and (2) initial ground level decreases being greatest at the bog boundary in the first time period and propagating inward with time.

Similar observations are made for the magnitude of strain (deformation) with peat thickness reducing by a mean of $23.5 \%( \pm 160.5 \%)$ and $2.0 \%( \pm 2.2 \%)$ in till and LC areas between 1991 and 2002, respectively, reducing to between $0.2 \%$ and $0.4 \%( \pm 0-0.5)$ between 2008 and 2017. To establish whether this may be attributable to greater peat thickness, calculations of the rate of subsidence per unit thickness of peat measure a mean rate of $4.33( \pm 15.7)$ and $1.95( \pm 2.18 \%)$ $\mathrm{mm} \cdot \mathrm{year}^{-1} \cdot \mathrm{m}^{-1}$ peat in till and LC areas between 1991 and 2002, respectively, reducing to between $0.57 \%$ and $0.82 \%( \pm 0.89-1.25)$ between 2008 and 2017. The mean accumulated subsidence for the till and LC areas is 48 and $30 \mathrm{~mm}$, respectively, between 1991 and 2017.

\subsection{Regional Groundwater Heads}

Measurements of piezometric head at boreholes A and B in 1991-1993, located close to the bog southern boundary and $400 \mathrm{~m}$ 
within the high bog area, respectively, reveal that the mean head at these locations was $0.5( \pm 0.1)$ and 0.8 $( \pm 0.15) \mathrm{m}$ higher than it was between 2010 and 2012. However, analysis of hydrograph records of four boreholes, east and west of the current delineated groundwater catchment (Figure 3), show no significant variation in mean piezometric head (within $0.05 \mathrm{~m}$ ). The regional groundwater table has decreased considerably within the central bog region, which is characterized by a north-south elongated catchment boundary and a steep hydraulic gradient draining southward into the regional drainage network (this remains relatively constant seasonally; Figures S2 and S3).

Time series of piezometric head measured between 2012 and 2017 in the till groundwater body (boreholes B and C) are presented in Figure 5. Head ranges over this period are 1.03 and $1.10 \mathrm{~m}$ for boreholes B and C, respectively. A notable decrease in annual minimum head $(>0.1 \mathrm{~m})$ is recorded at borehole $\mathrm{C}$, while the opposite trend is observed at borehole B. Both boreholes are in the same groundwater body, indicating that the piezometer underneath the bog (borehole $\mathrm{C}$ ) is continually being drained, similar to the regional piezometric head decreases between 1991 and 2012. The apparent increase in head at borehole B may be associated with changes in the wider catchment area, as no discernible changes are observed in annual peak heads. The previously noted decrease in head at borehole B since 1991-1993 levels can be ascribed to drain modification/deepening that occurred in the area at that time but has since been left unaltered.

\subsection{Peat Piezometric Heads}

The mean potentiometric head at the base of peat is shown in Figure 3. There are three notable features and patterns to be observed from these potentiometric contours: (1) the steep hydraulic gradient from the groundwater-fed drain to $>200 \mathrm{~m}$ inside central area of the bog; (2) the drainage pattern in the south-eastern area of the bog, coincident with the occurrence of underlying till and sand deposits; and (3) the drainage pattern in the south-western area of the bog, also coincident with the occurrence of underlying till deposits. Also shown is the mean decrease in piezometric head at the base of peat from 1991-1993 to 2010-2012. A decrease of $>1.6 \mathrm{~m}$ is observed toward the southern bog boundary and $>0.6 \mathrm{~m}$ within $500 \mathrm{~m}$ of the bog boundary, coincident with the potentiometric drainage patterns. A large decrease is also observed at the bog's western boundary, while no discernible change in piezometric head is recorded on the bog's eastern boundary. Comparison of subsidence and mean piezometric head (1991-2012) reveals a linear relationship, with declines in ground level of $>0.1 \mathrm{~m}$ occurring where head declines are $>0.2 \mathrm{~m}$ (Figure S5).

\subsection{Groundwater Discharge}

Figure 6a presents hydrographs reflecting the water level dynamics at the groundwater-fed drain bordering the southern bog boundary (point F on Figure 3) between February 2017 and February 2018. Discrete groundwater seepages are evident at numerous locations along the southern bog boundary (EC $>200$ $\mu \mathrm{S} / \mathrm{cm}$; between 400 and $700 \mu \mathrm{S} / \mathrm{cm}$ in the till groundwater body); however, in this area, groundwater discharge becomes increasingly diffuse and flows into the regional drainage network (Figure S6). Over the duration of the time series, there is a consistent upward gradient from the base of till to the drain, with piezometric heads 0.2 to $0.8 \mathrm{~m}$ greater than stage level. Artesian conditions are characteristic of the cut bog area in general, with four piezometers in the till unit all measuring consistent upward directions in hydraulic gradient. While peat is generally considered to isolate regional groundwater flows from surface drainage, there is an almost consistently upward direction in hydraulic gradient from piezometric head at the base of peat to the drain (Figure 6b), despite the thickness of peat beneath $(3 \mathrm{~m})$, indicating that there are preferential pathways for groundwater discharge to the drain. This gradient reverses in periods of high stage levels, meaning the drain experiences periodic flow reversals in hydraulic gradient direction, though upward flows dominate the hydrograph time series in all but the wettest periods (77\% of the presented time series).

Figure $6 \mathrm{c}$ shows the temporal fluctuation in EC at the drain between July and October 2017. There is a close inverse correlation between stage water level and $\mathrm{EC}$ value, with $\mathrm{EC}$ values increasing to $\sim 350 \mu \mathrm{S} / \mathrm{cm}$ at low flows as the stage recedes, while decreasing rapidly, to values as low as $\sim 50 \mu \mathrm{S} / \mathrm{cm}$, in response to rainfall. Thus, the drain is continually receiving baseflow (and high EC) but when it rains receives direct runoff from the bog (low EC) water, thereby suppressing the net EC values. The sharp reductions in EC from July to September, when the difference between stage elevation and peat head is still negative (i.e., upward gradient), is a result of rapid channelized runoff from the bog via ephemeral flow channels. 

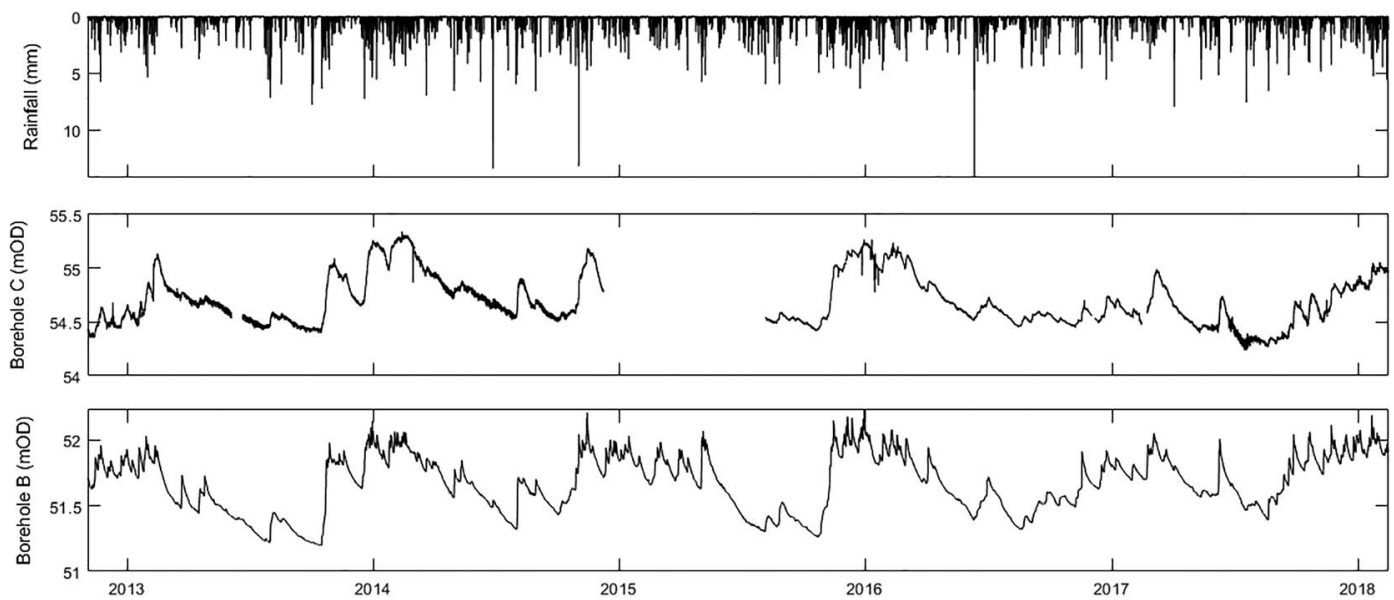

Figure 5. Rainfall and hydrographs of piezometric head from till unit underlying bog (borehole C) and adjacent to bog (borehole B) between 2012 and 2017.

A hydrogeological cross-sectional profile through a groundwater flowline (Figure 2) where significant subsidence has occurred since 1991 is shown in Figure 7. The drawdown of piezometric heads in the peat is evidenced by the hydraulic gradient of the equipotential lines toward the drain. The drain laterally draws down the water table within an extent of approximately $50 \mathrm{~m}$. From this point, ARB is mapped on the bog surface (or acrotelm) in an area of shallow topographic gradient. However, where the peat rests on the till mound, a drawdown in piezometric head is observed, and no ARB (i.e., acrotelm) is mapped on the bog surface. Topographic gradients are high in this area $(>0.5 \%)$, and it is also where large levels of subsidence have occurred $(>0.1 \mathrm{~m})$. Thus, the lateral effect of drawdown by the groundwater-fed drain extends beyond the bog margin and between 150 and $250 \mathrm{~m}$ inside the bog area, where the till mound occurs. Further inside the bog, ARB reappears where there are shallow equipotential gradients.

\subsection{Hydraulic Conductivity}

$K$ results from till were highly variable, spanning almost 6 orders of magnitude, indicative of the heterogeneous matrix composition of the unit. While a median $K$ value of $1.02 \mathrm{~m} / \mathrm{day}(n=16)$ is found (Figure 8), gravel-dominated sequences gave very high $K$ values (maximum of $16.5 \mathrm{~m} /$ day) and clay-dominated intervals low $K$ values (minimum of $2.24 \times 10^{-5} \mathrm{~m} /$ day). The higher permeability units $(>2 \mathrm{~m} /$ day) are found
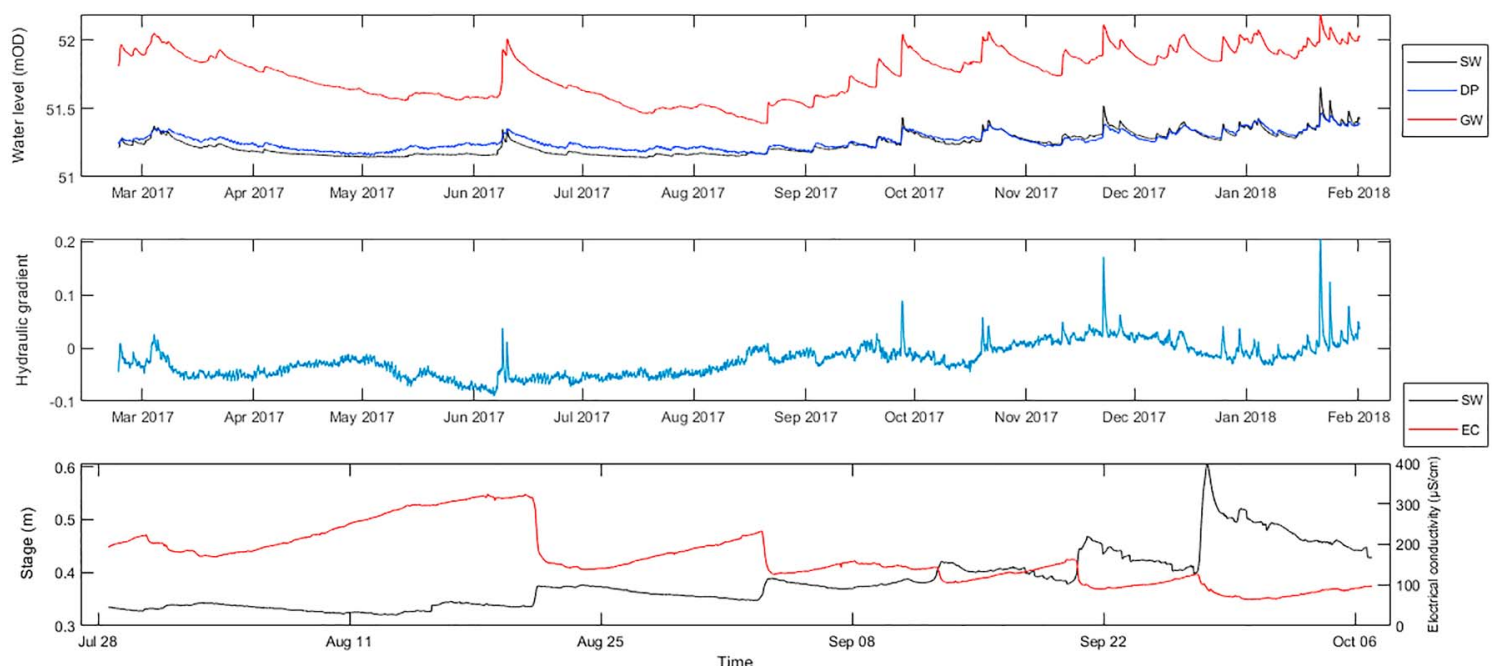

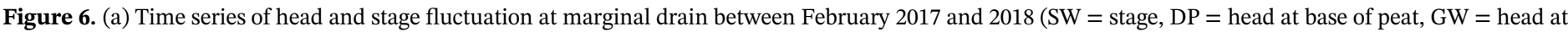
base of till); (b) hydraulic gradient between stage and peat head; and (c) fluctuation in stage and electrical conductivity at low and high flows. 


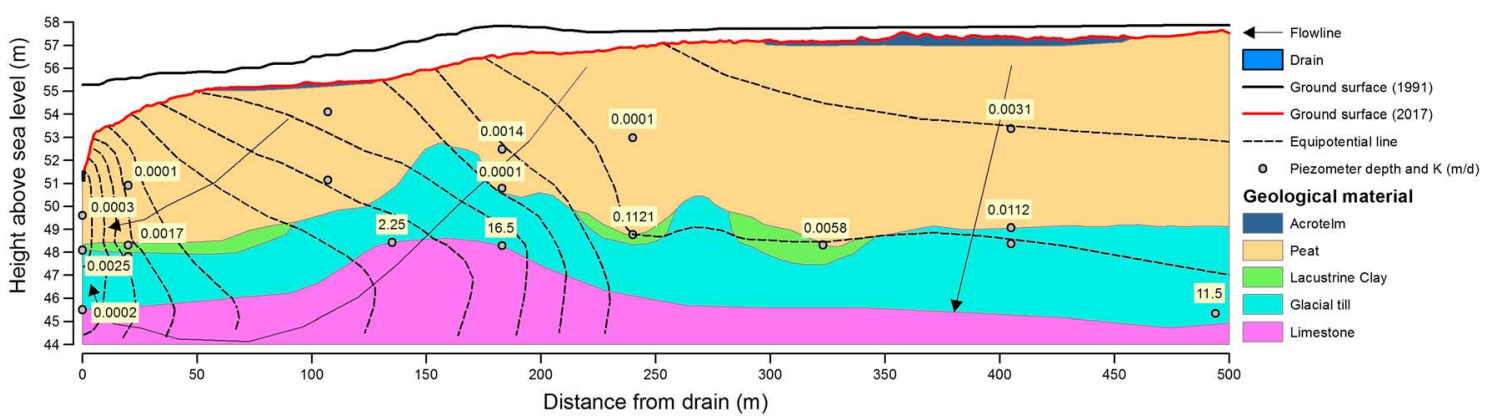

Figure 7. Hydrogeological cross-section through groundwater flow line. Note. Equipotential lines are set at 0.5-m intervals.

in elevated till areas, with the largest recorded $K$ values ( $>10 \mathrm{~m} /$ day) encountered at the northeast-southwest trending ridge underlying the bog. In contrast, the $K$ of LC is in the order of $10^{-7} \mathrm{~m} /$ day.

$K$ results from piezometers at the base of peat column across the bog area exhibit a strong variation in $K$, over approximately 5 orders of magnitude (Figure 8), with a median $K$ of $2.22 \times 10^{-3} \mathrm{~m} / \mathrm{day}(n=46)$. However, the variability in $K$ reduces to approximately 2 orders of magnitude where peat overlies LC $(n=25)$; median $K$ is slightly higher where peat overlies LC $\left(2.52 \times 10^{-3} \mathrm{~m} /\right.$ day $)$, than till $\left(1.39 \times 10^{-3} \mathrm{~m} /\right.$ day $)$. Higher median $K$ values $\left(1.15 \times 10^{-2} \mathrm{~m} /\right.$ day, $\left.n=23\right)$ are measured in the midsection peat, with less variability than in basal peat, spanning approximately 2 orders of magnitude. Median $K$ for midsection peat decreases from $4.17 \times$ $10^{-2} \mathrm{~m} /$ day $(n=16)$ in LC areas to $3.1 \times 10^{-3} \mathrm{~m} /$ day in till areas. These results are in the range typically found in peat (e.g., Beckwith et al., 2003; Letts et al., 2000; Quinton et al., 2008). However, there is significant spatial variability in deep peat $K$ (Figures 3 and 8). High $K$ values $\left(>10^{-2} \mathrm{~m} /\right.$ day) are encountered where till underlies the peat and where there is deep peat drainage, as evidenced by the drainage pattern in the potentiometric surface. High $K$ values $\left(>10^{-2} \mathrm{~m} /\right.$ day) are typically reported for fibrous peats close to the peatland surface (e.g., Quinton et al., 2008) and not for deep peat (e.g., Morris et al., 2015), such as the depths reported here.

Repeat $K$ measurements were carried out on deep peat piezometers that were first measured in 1991-1993 (Figure 3). It is found that median $K$ decreased from $2.9 \times 10^{-3}$ to $1.6 \times 10^{-3} \mathrm{~m} /$ day over this period $(n=16)$. Assessing accurate changes in peat $K$, from two different time periods, is problematic due to the elastic nature of the material and the methods used for calculation. However, in this study changes within $50 \%$ are considered nonsignificant. It is found that at three measurement locations, $K$ increased by 1 to 2 orders of magnitude and

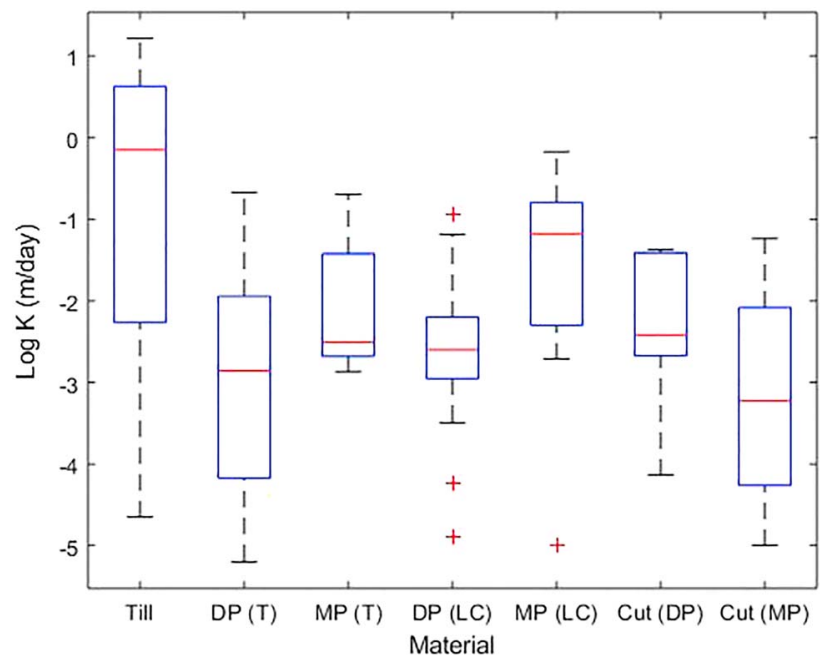

Figure 8. Box plots of logarithm of hydraulic for till; the base of peat (DP) and midway through the peat profile (MP) for areas of natural bog underlain by till (T) and lacustrine clay (LC); cut and drained peat (Cut). decreased by 1 order of magnitude at five locations. Where $K$ decreased, changes in $K$ value are within $50-100 \%$ of the original measurement. However, where $K$ increased, it is $300-3,000 \%$ greater than the original measurement. It is hypothesized that this increase is due to the introduction of secondary porosity to the base of the peat profile (i.e., macropores).

While mean $K$ has decreased, mean vertical hydraulic gradients have increased from $0.07( \pm 0.07)$ to $0.1( \pm 0.08)$, and mean vertical specific discharge (Darcian flux) have increased from $1.0( \pm 2.7)$ to $1.4( \pm 2.8) \mathrm{mm} /$ day in this time period, resulting in a net downward flow increase of $30 \%$ to $40 \%$. The locations where $K$ has increased are associated with the areas measuring significant decrease in piezometric head (Figure 3) and changes in peat thickness of $>5 \%$ (Figure $4 \mathrm{~b}$ ). All piezometers registering high $K$ values are located in this area, suggesting that it is a zone of enhanced groundwater recharge, due to the density of the apparent macropores. This is also apparent on Figure 7, with a strong drawdown in the equipotential line close to the till ridge, where the $K$ of peat is very high $\left(1.12 \times 10^{-1} \mathrm{~m} /\right.$ day $)$. The distinct heterogeneity of the peat profile can also be observed on this section, with $K$ of basal peat generally higher than midsection peat, in contrast with the global means across the entire bog. 
Table 2

Decorrelation Lag Times (at 0.2 Level) of Active Raised Bog (ARB) and Degraded Peat

\begin{tabular}{|c|c|c|c|c|c|c|c|c|}
\hline & \multicolumn{4}{|c|}{ Summer (Apr-Sept) } & \multicolumn{4}{|c|}{ Winter (Oct-Mar) } \\
\hline & \multicolumn{2}{|c|}{ ARB } & \multicolumn{2}{|c|}{ Degraded } & \multicolumn{2}{|c|}{$\mathrm{ARB}$} & \multicolumn{2}{|c|}{ Degraded } \\
\hline & $2015 / 2016$ & $2016 / 2017$ & $2015 / 2016$ & $2016 / 2017$ & $2015 / 2016$ & $2016 / 2017$ & $2015 / 2016$ & $2016 / 2017$ \\
\hline Peat & 43.0 & 30.6 & 15.4 & 12.9 & 41.4 & 39.7 & 13.0 & 12.8 \\
\hline Phreatic & 15.7 & 22.9 & 15.3 & 14.1 & 20.5 & 10.7 & 15.0 & 13.9 \\
\hline
\end{tabular}

Note. Years 1 and 2 refer to the 2015/2016 and 2016/2017 hydrological years, respectively (defined as 1 October to 30 September in Ireland). Data further partitioned into the dryer (April to September inclusive) and wetter half of each year (October to March inclusive) to examine seasonal variability. Peat refers to piezometric head at the base of the peat column, and phreatic is the unconfined water table.

The macropore effect on bog hydrology is further demonstrated by autocorrelation analysis, which was deployed to investigate the simultaneous response of water table and piezometric head at depth in peat to rainfall, in two areas of contrasting ecology. Mean water levels were $0.008( \pm 0.04)$ and $0.72( \pm 0.15)$ mbGL ( $\mathrm{m}$ below ground level) for water table and piezometric head in the ARB supported area and $0.15( \pm 0.06)$ and $1.45( \pm 0.25)$ mbGL for water table and piezometric head in the damaged peat area. The piezometric head at depth in the ARB-supported area consistently showed a longer memory than the overlying phreatic water table across all analysis periods, highlighting the ability of the intact peat to sustain elevated water levels irrespective of overlying phreatic pressures (Table 2). Conversely, the behavior of the degraded peat is barely distinguishable from that of the phreatic table, indicating that the area with damaged peat has become unconfined.

\section{Discussion}

\subsection{Groundwater Drainage}

Raised bogs are typically considered ombrotrophic wetlands, in that rainfall acts as the dominant control on their hydrological and ecological functioning. As such, they are conceptualized as hydrological units that are isolated from groundwater bodies and regional aquifer systems due to low permeability peat restricting downward seepage losses and underlying low permeable substrates isolating the peatland from deeper groundwater flows. However, this study has confirmed that regional groundwater can interact with these peatland systems where permeable deposits are present (Siegel et al., 1995, Glaser et al., 1997; Reeve et al., 2000; Auterives et al., 2011; Whittington et al., 2012) and has demonstrated the importance of this connection in conserving ecological functioning and in guiding restoration schemes, while highlighting the role of regional groundwater as an environmental supporting condition for raised bogs. Moreover, the characterization of peat as a dual porosity medium, permitting preferential flow through macropores within a low hydraulic conductivity peat matrix (Rezanezhad et al., 2012; Rossi et al., 2012), is fundamental to this conceptualization.

The extent of glacial retreat across much of Europe and North America suggests that the presence of permeable substrates beneath peat is more common than currently recognized. At Clara, a considerable proportion of the peatland is underlain by glacial till deposits. The mean permeability of this deposit is 4 orders of magnitude higher than the LC deposits underlying the remainder of the bog and is considered a local aquifer system in this region. The bog is therefore locally in hydraulic contact with the aquifer system, and a significant part of the groundwater in peat flows downward. This is indicated by the drawdown in piezometric head at the base of peat induced by the till ridge underlying the bog and is similar to the results reported by Reeve et al. (2000), where modeling simulations of peat overlying high-permeability substrates show a predominance for vertical flow in the deep peat. A hydraulic connection between the peat and till means that changes to aquifer piezometric head conditions can induce a corresponding effect on piezometric heads within the main peat body.

The network of piezometers installed to measure piezometric head in the till unit beneath the bog, and in the surrounding landscape area, reveals an elongated groundwater catchment area with steep lateral hydraulic gradients underlying the bog. The drawdown of the groundwater potentiometric head is due to peripheral 
drainage, which is demonstrated to intercept regional groundwater flows and be a zone for continuous groundwater discharge. This drainage system formed as peat was removed from the bog's southern boundary and postdates a hydrological study conducted in 1991-1993. Comparison of piezometric heads in till between 1991-1993 and 2010-2012 reveals a 0.5-0.8-m decline in head within the delineated groundwater catchment, while no significant changes are measured outside of the catchment. Concurrent with this is a measured decline in piezometric head in peat, with levels reducing $>1.6 \mathrm{~m}$ close to the bog margin to $>0.6 \mathrm{~m}$ within $500 \mathrm{~m}$ from the margin. The peat potentiometric surface shows a distinct drainage pattern in an area where peat is underlain by till but also where it is underlain by sand deposits overlying LC areas, which are in hydraulic continuity with an underlying till ridge, indicating a very complicated threedimensional groundwater flow system. Regional drainage has resulted in the decline of deep groundwater heads in the till substrates leading to peat drainage and subsidence.

\subsection{Subsidence Mechanisms}

Settlement levels in excess of $1 \mathrm{~m}$ are measured $>170 \mathrm{~m}$ from the bog's southern boundary, and discernible changes of $>0.1 \mathrm{~m}$ are measured as propagating as far as $900 \mathrm{~m}$ inside the bog complex. Greatest levels of subsidence are associated with the highly permeable ( $>10 \mathrm{~m} /$ day) till ridge. Similar to other subsidence studies (e.g., Hooijer et al., 2012; Wösten et al., 1997), the majority of peat settlement occurred within the first 10 years following drainage, though it is likely that this occurred much sooner (before 2002). In the period post 2008, subsidence appears to have stabilized around the southern areas of the bog, with local increases (diverting surface flows), but is propagating into the central and northern regions of the bog that are largely underlain by till. While subsidence appears to be continuing at a near constant rate (4-6 mm/year), the 2017 digital terrain model survey was conducted in a summer period, where ground levels are expected to be lower than in winter periods, which is when all other surveys took place. Thus, these rates cannot be considered absolute due to the dynamic nature of ground level fluctuation associated with peatland environments with ARB conditions (the oscillation of the peat surface at Clara is $<10 \mathrm{~cm}$ in ARB areas but can be > 30 cm; e.g., Reeve et al., 2013; Howie \& Hebda , 2018); however, the consistent downward trend in ground surface levels is strongly indicative of an underlying drainage process inducing peat settlement

Subsidence of peat soils occurs mainly by oxidation above the water table or by compression below (Schothorst, 1977; Schlotzhauer \& Price, 1999); bio-oxidation processes are generally reported as the primary mechanism driving subsidence of peat soils. At Clara, the bog system still contains a significant area of ARB (though this is degrading, with losses $>40 \%$ reported since 1991; NPWS, 2017) and a water table close to the ground surface, suggesting the water table regulates itself to shifting ground levels. Oxidation processes possibly effect the ecologically degraded areas, though minimal ground level changes are detected in the bog's marginal areas, where these degraded conditions occur. Compression is therefore considered the dominant consolidation mechanism, induced by the decrease in piezometric head at the base of peat and a resultant increase in effective stress. The forces driving this decrease in piezometric head is the drainage of the till aquifer via the groundwater-fed channel. In contrast to this, no significant ground level changes have been measured at Clara East, which is wholly underlain by LC.

\subsection{Peat Hydraulic Properties}

Comparison of $K$ measured from piezometer test responses indicates that there have been no significant change in peat properties in areas experiencing limited $(<1 \%)$ subsidence. These conditions contrast with changes in peat properties in areas experiencing subsidence in excess of 5\% of the 1991 peat thickness and where a drainage pattern is apparent from the peat potentiometric surface; these areas display marked increases in hydraulic conductivity by up to two orders of magnitude. In this area, there is a concentration of high $K$ basal peat, indicating that the units are connected. Concurrently, decreases in $K$ by one order of magnitude are found in the same region of the bog, indicating compaction and loss of pore volume. Overall, vertical (downward) hydraulic gradients have increased with an estimated increase in downward flux at the base of peat increasing by 30-40\% since the 1991-1993 study.

It has been observed by Reeve et al. (2013) that ground level changes can be explained by variations in the peat strength (e.g., differences in wood content), gas content in the peat, or loading at the surface due to differences in living biomass. At Clara, it appears that the response of peat to drainage is both plastic deformation, with a decrease in peat $K$, and brittle deformation, with the introduction of subsurface flow 
paths/cracks. The hydraulic properties of peat have thereby changed significantly post-drainage. While the water released from the peat by compression has reduced its storativity and thereby increased its bulk density, preferential pathways for groundwater flow have been introduced by the cracking/fissuring of the peat, that is, macropore connectivity in the low permeability peat matrix. Rossi et al. (2012) have previously found that preferential flow paths, and fracturing, are most prevalent in areas of deeper peat, and this appears to be the case at Clara. Where this occurs, the peat is no longer confined from the underlying till substrates. This is indicated by the response of piezometric heads at depth, with rapid drainage responses, similar to the water table, found in areas of damaged peat, while a damped response is measured in areas supporting ARB.

\subsection{Issues for Management}

Peatland ecosystems are generally considered to be resilient to fluctuations in hydrological and climatic conditions (e.g., Gallego-Sala et al., 2018). However, these ecosystems are resilient only when their structure is left intact. This is not the case for the majority of peatlands in Ireland, which have been fragmented and drained by a long history of exploitation. The restoration of organic soils that have undergone subsidence is particularly challenging because of changes to hydraulic gradients and water storage capacity (Price, 2003). Deformation of the bog surface alters peripheral water slope gradients and promotes ecological desiccation where slope gradients have increased. The introduction of subsurface preferential pathways means that any management designed to arrest subsidence and restore water levels must reinstate/increase groundwater heads and reduce hydraulic gradients between peat and substrate to restore the bog's hydrological balance. To achieve this, the discharge outlets for groundwater flows emanating from beneath the bog system must be removed. However, while managing regional piezometric heads can conceivably raise hydrostatic pressures in this manner, the pathways of preferential flow will not be removed. While these pathways may now be permanent features, re-establishing the vertical hydraulic gradients will arrest the subsidence although the impact on peatland ecohydrology at the surface may be permanent. Thus, conservation management requires a regional approach and maintenance of the relevant environmental hydrological conditions, including deeper groundwater heads.

The interaction of peatland systems with regional groundwater flow systems is rarely measured in ecohydrological studies. It is demonstrated here that piezometric head, both in peat and underlying mineral substrates, can be an important environmental supporting condition in raised bog hydrology. At Clara, the decline of these heads resulting from subsurface drainage is shown to induce considerable subsidence. The implication of this analysis is that care must be taken in the placement of stations to monitor the long-term trends in regional groundwater dynamics. While installing monitoring points may also be extremely difficult, the information provided is critical, both with regard to insights into peatland hydrology and with respect to informing peatland management and assessing the effects groundwater withdrawal, such as through changes in land management, has on ecosystem functioning. However, the propagation of the effects of drainage of regional groundwater at the margin of a bog may have limited range depending on the hydrogeology and may be difficult to delineate.

\section{Conclusions}

Raised bogs are typically conceptualized as wetlands isolated from underlying regional groundwater bodies or aquifer systems. However, the generalization that peat bogs can only be conceived as existing on lowpermeability substrates, such as lacustrine clays, is not always true, with this study demonstrating that highly permeable (>10 m/day) glacial deposits can also support peat overburden. The absence of a basal sealing layer therefore places the bog in hydraulic continuity with the regional groundwater system. In this context, changes in regional hydrology can potentially alter peatland dynamics and hydrogeological properties as well as the dependent ecology. This is proven to be the case at Clara Bog, where a 28 -year record of water level, topography, and hydraulic conductivity has conclusively demonstrated the impact of peripheral groundwater drainage (caused by marginal peat cutting) on uncut raised bog hydrology. Despite the bog having little in the way of surface drainage, subsidence levels of $>1 \mathrm{~m}$ are measured up to $170 \mathrm{~m}$ from the bog margin and decrease to $>0.1$ up to $900 \mathrm{~m}$. Subsidence has continued at a near constant rate (4-6 mm/year) since measurements began in 1991. While bog surface levels have stabilized at the bog margin, they have continued to decline further inside the bog. 
Intense localized consolidation of peat $(>5 \%)$ was measured in areas underlain by glacial till and also where thin sequences of coarse sand overly lacustrine clay. While the consolidation of peat is typically driven by bio-oxidation processes, the mechanism causing subsidence on the western side of the bog complex is a decline in piezometric head at the base of peat $(<1.65 \mathrm{~m})$, driven by drainage of the regional groundwater system. This process has simultaneously decreased hydraulic conductivity in the basal peat, while increasing hydraulic conductivity by over 2 orders of magnitude in the peat profile where peat is in contact with permeable substrate. Where this occurs, deep peat hydraulic conductivity is $>0.01 \mathrm{~m} /$ day, far greater than normally encountered in deep peat deposits, with significant vertical water losses to the underlying substrate. The normally heavily damped response of groundwater in deep peat to rainfall becomes much more reactive, indicating significant subsurface cracking (macroporosity) within the low-permeability matrix, developing as a result of subsidence. Thus, the damage resulting from disturbance to the regional groundwater is reflected in the altered hydrogeological properties of peat, consequent subsidence, and a significant decline in peat-forming vegetation ( $>40 \%$ since 1991), with implications for the carbon balance of the bog and its ecological conservation. The restoration of a raised bog that has been impacted in this way is greatly complicated by the occurrence of such subsurface preferential pathways, and a regional approach to hydrological management is required.

\section{Acknowledgments}

This study has been funded by both the National Parks and Wildlife Service (NPWS) and the Environmental Protection Agency (EPA) in Ireland. All LiDAR data were provided by the NPWS. Special acknowledgement is also given to Jan Streefkerk, formerly with Staatsbosboheer (Netherlands), and Jim Ryan (NPWS) for guiding the grounding work of this project. (regans@tcd.ie). Summary data are included as supporting information and at https://figshare.com/articles/Regan et_al_2019_summary-data_xlsx/ 8248760 .

\section{References}

Auterives, C., Aquilina, L., Bour, O., Davranche, M., \& Paquereau, V. (2011). Contribution of climatic and anthropogenic effects to the hydric deficit of peatlands. Hydrological Processes, 25(18), 2890-2906. https://doi.org/10.1002/hyp.8052

Baird, A. J., Low, R., Young, D., Swindles, G. T., Lopez, O. R., \& Page, S. (2017). High permeability explains the vulnerability of the carbon store in drained tropical peatlands. Geophysical Research Letters, 44, 1333-1339. https://doi.org/10.1002/2016GL072245

Baird, A. J., Surridge, B. W. J., \& Money, R. P. (2004). An assessment of the piezometer method for measuring the hydraulic conductivity of a Cladium mariscus-Phragmites australis root mat in a Norfolk (UK) fen. Hydrological Processes, 18(2), 275-291. https://doi.org/ 10.1002/hyp.1375

Beckwith, C. W., Baird, A. J., \& Heathwaite, A. L. (2003). Anisotropy and depth-related heterogeneity of hydraulic conductivity in a bog peat. I: Laboratory measurements. Hydrological Processes, 17(1), 89-101. https://doi.org/10.1002/hyp.1116

Belyea, L. R., \& Clymo, R. (2001). Feedback control of the rate of peat formation. Proceedings of the Royal Society of London B: Biological Sciences, 268(1473), 1315-1321. https://doi.org/10.1098/rspb.2001.1665

Box, G. E., Jenkins, G. M., Reinsel, G. C., \& Ljung, G. M. (2015). Time series analysis: Forecasting and control. Hoboken, NJ: John Wiley \& Sons.

Council of the European Communities (1992). Council Directive 92/43/EEC of 21. May 1992 on the conservation of natural habitats and of wild fauna and flora. Official Journal of the European Communities, 35, 7-50. http://ec.europa.eu/environment/nature/legislation/ habitatsdirective/index_en.htm

Devito, K. J., Waddington, J. M., \& Branfireun, B. A. (1997). Flow reversals in peatlands influenced by local groundwater systems. Hydrological Processes, 11(1), 103-110. https://doi.org/10.1002/(SICI)1099-1085(199701)11:1<103::AID-HYP417>3.0.CO;2-E

Fraser, C. J. D., Roulet, N. T., \& Moore, T. R. (2001). Hydrology and dissolved organic carbon biogeochemistry in an ombrotrophic bog. Hydrological Processes, 15(16), 3151-3166. https://doi.org/10.1002/hyp.322

Gallego-Sala, A. V., Charman, D. J., Brewer, S., Page, S. E., Prentice, I. C., Friedlingstein, P., et al. (2018). Latitudinal limits to the predicted increase of the peatland carbon sink with warming. Nature climate change, 8(10), 907-913. https://doi.org/10.1038/s41558018-0271-1

Glaser, P. H., Siegel, D. I., Romanowicz, E. A., \& Shen, Y. P. (1997). Regional linkages between raised bogs and the climate, groundwater, and landscape of north-western Minnesota. Journal of Ecology, 85(1), 3-16. https://doi.org/10.2307/2960623

Hobbs, N. (1986). Mire morphology and the properties and behaviour of some British and foreign peats. Quarterly Journal of Engineering Geology and Hydrogeology, 19(1), 7-80. https://doi.org/10.1144/GSL.QJEG.1986.019.01.02

Holden, J., \& Burt, T. (2003). Hydraulic conductivity in upland blanket peat: Measurement and variability. Hydrological Processes, 17(6), 1227-1237. https://doi.org/10.1002/hyp.1182

Hooijer, A., Page, S., Jauhiainen, J., Lee, W. A., Lu, X. X., Idris, A., \& Anshari, G. (2012). Subsidence and carbon loss in drained tropical peatlands. Biogeosciences, 9(3), 1053-1071. https://doi.org/10.5194/bg-9-1053-2012

Howie, S. A., \& Hebda, R. J. (2018). Bog surface oscillation (mire breathing): A useful measure in raised bog restoration. Hydrological Processes, 32(11), 1518-1530. https://doi.org/10.1002/hyp.11622

Hvorslev, M. J. (1951). "Time lag and soil permeability in ground-water observations."

Ingram, H. A. P. (1983). In A. J. P. Gore (Ed.), Hydrology. Mires: Swamp, bog, fen and moor, Ecosystems of the world, (Vol. 4A, pp. 67-159). Amsterdam: Elsevier.

Johansen, O. M., Pedersen, M. L., \& Jensen, J. B. (2011). Effect of groundwater abstraction on fen ecosystems. Journal of hydrology, 402(3-4), 357-366. https://doi.org/10.1016/j.jhydrol.2011.03.031

Joosten, H. (2009). "The global peatland $\mathrm{CO}_{2}$ picture: Peatland status and drainage-related emissions in all countries of the world."

Kværner, J., \& Snilsberg, P. (2011). Groundwater hydrology of boreal peatlands above a bedrock tunnel-Drainage impacts and surface water groundwater interactions. Journal of hydrology, 403(3-4), 278-291. https://doi.org/10.1016/j.jhydrol.2011.04.006

Leifeld, J., \& Menichetti, L. (2018). The underappreciated potential of peatlands in global climate change mitigation strategies. Nature Communications, 9(1), 1071. https://doi.org/10.1038/s41467-018-03406-6

Letts, M. G., Roulet, N. T., Comer, N. T., Skarupa, M. R., \& Verseghy, D. L. (2000). Parametrization of peatland hydraulic properties for the Canadian land surface scheme. Atmosphere-Ocean, 38(1), 141-160. https://doi.org/10.1080/07055900.2000.9649643

Lowry, C. S., Fratta, D., \& Anderson, M. P. (2009). Ground penetrating radar and spring formation in a groundwater dominated peat wetland. Journal of hydrology, 373(1-2), 68-79. https://doi.org/10.1016/j.jhydrol.2009.04.023 
Liu, H., Janssen, M., \& Lennartz, B. (2016). Changes in flow and transport patterns in fen peat following soil degradation. European journal of soil science, 67(6), 763-772. https://doi.org/10.1111/ejss.12380

Moore, P. A., Morris, P. J., \& Waddington, J. M. (2015). Multi-decadal water table manipulation alters peatland hydraulic structure and moisture retention. Hydrological Processes, 29(13), 2970-2982. https://doi.org/10.1002/hyp.10416

Morris, P. J., Baird, A. J., \& Belyea, L. R. (2015). Bridging the gap between models and measurements of peat hydraulic conductivity. Water Resources Research, 51, 5353-5364. https://doi.org/10.1002/2015WR017264

NPWS (2016). Clara Bog SAC. Conservation objectives supporting document raised bog habitats. Dublin, Ireland: Department of Culture, Heritage and the Gaeltacht.

NPWS (2017). National raised bog special areas of conservation management plan 2017-2022. Dublin, Ireland: Department of Culture, Heritage and the Gaeltacht.

Oosterwoud, M., van der Ploeg, M., van der Schaaf, S., \& van der Zee, S. (2017). Variation in hydrologic connectivity as a result of microtopography explained by discharge to catchment size relationship. Hydrological Processes, 31(15), 2683-2699. https://doi.org/10.1002/ hyp. 11164

Padilla, A., \& Pulido-Bosch, A. (1995). Study of hydrographs of karstic aquifers by means of correlation and cross-spectral analysis. Journal of hydrology, 168(1-4), 73-89. https://doi.org/10.1016/0022-1694(94)02648-U

Price, J. S. (2003). Role and character of seasonal peat soil deformation on the hydrology of undisturbed and cutover peatlands. Water Resources Research, 39(9), 1241. https://doi.org/10.1029/2002WR001302

Price, J. S. (1996). Hydrology and microclimate of a partly restored cutover bog, Quebec. Hydrological processes, 10(10), 1263-1272. https://doi.org/10.1002/(SICI)1099-1085(199610)10:10<1263::AID-HYP458>3.0.CO;2-1

Quillet, A., Larocque, M., Pellerin, S., Cloutier, V., Ferlatte, M., Paniconi, C., \& Bourgault, M. A. (2017). The role of hydrogeological setting in two Canadian peatlands investigated through 2D steady-state groundwater flow modelling. Hydrological Sciences Journal, 62(15), 2541-2557. https://doi.org/10.1080/02626667.2017.1391387

Quinton, W. L., Elliot, T., Price, J. S., Rezanezhad, F., \& Heck, R. (2009). Measuring physical and hydraulic properties of peat from X-ray tomography. Geoderma, 153(1-2), 269-277. https://doi.org/10.1016/j.geoderma.2009.08.010

Quinton, W. L., Hayashi, M., \& Carey, S. K. (2008). Peat hydraulic conductivity in cold regions and its relation to pore size and geometry. Hydrological Processes: An International Journal, 22(15), 2829-2837. https://doi.org/10.1002/hyp.7027

Ramsar (1971). Convention on Wetlands of International Importance especially as Waterfowl Habitat. Ramsar (Iran), 2 February 1971. UN Treaty Series No. 14583. As amended by the Paris Protocol, 3 December 1982, and Regina Amendments, 28 May 1987.

Reeve, A. S., Evensen, R., Glaser, P. H., Siegel, D. I., \& Rosenberry, D. (2006). Flow path oscillations in transient ground-water simulations of large peatland systems. Journal of hydrology, 316(1-4), 313-324. https://doi.org/10.1016/j.jhydrol.2005.05.005

Reeve, A. S., Glaser, P. H., \& Rosenberry, D. O. (2013). Seasonal changes in peatland surface elevation recorded at GPS stations in the Red Lake Peatlands, northern Minnesota, USA. Journal of Geophysical Research: Biogeosciences, 118, 1616-1626. https://doi.org/10.1002/ 2013JG002404

Reeve, A. S., Siegel, D. I., \& Glaser, P. H. (2000). Simulating vertical flow in large peatlands. Journal of hydrology, 227(1-4), 207-217. https://doi.org/10.1016/S0022-1694(99)00183-3

Rezanezhad, F., Price, J. S., \& Craig, J. R. (2012). The effects of dual porosity on transport and retardation in peat: A laboratory experiment Canadian Journal of Soil Science, 92(5), 723-732. https://doi.org/10.4141/cjss2011-050

Robroek, B. J., Schouten, M. G., Limpens, J., Berendse, F., \& Poorter, H. (2009). Interactive effects of water table and precipitation on net $\mathrm{CO}_{2}$ assimilation of three co-occurring sphagnum mosses differing in distribution above the water table. Global Change Biology, 15(3), 680-691. https://doi.org/10.1111/j.1365-2486.2008.01724.x

Rossi, P. M., Ala-aho, P., Ronkanen, A. K., \& Kløve, B. (2012). Groundwater-surface water interaction between an esker aquifer and a drained fen. Journal of hydrology, 432, 52-60.

Roulet, N. T. (2000). Peatlands, carbon storage, greenhouse gases, and the Kyoto Protocol: Prospects and significance for Canada. Wetlands, 20(4), 605-615. https://doi.org/10.1672/0277-5212(2000)020[0605:PCSGGA]2.0.CO;2

Schlotzhauer, S. M., \& Price, J. S. (1999). Soil water flow dynamics in a managed cutover peat field, Quebec: Field and laboratory investigations. Water Resources Research, 35(12), 3675-3683. https://doi.org/10.1029/1999WR900126

Schouten, M. G. (2002). Conservation and restoration of raised bogs: Geological, hydrological and ecological studies. Dublin: The Government Stationary Office.

Schouwenaars, J. (1993). Hydrological differences between bogs and bog-relicts and consequences for bog restoration, (pp. 217-224). Netherlands-Wetlands: Springer.

Schothorst, C. J. (1977). Subsidence of low moor peat soils in the western Netherlands. Geoderma, 17(4), 265-291. https://doi.org/10.1016/ 0016-7061(77)90089-1

Siegel, D. I., \& Glaser, P. H. (1987). Groundwater flow in a bog-fen complex, Lost River Peatland, northern Minnesota. The Journal of Ecology, 75(3), 743-754. https://doi.org/10.2307/2260203

Siegel, D. I., Reeve, A. S., Glaser, P. H., \& Romanowicz, E. A. (1995). Climate-driven flushing of pore water in peatlands. Nature, 374(6522), 531-533. https://doi.org/10.1038/374531a0

Van Breemen, N. (1995). How sphagnum bogs down other plants. Trends in Ecology \& Evolution, 10(7), 270-275. https://doi.org/10.1016/ 0169-5347(95)90007-1

Van der Schaaf, S. (1999). Analysis of the hydrology of raised bogs in the Irish Midlands: A case study of Raheenmore Bog and Clara Bog, unpublished $\mathrm{PhD}$ thesis.

Van der Schaaf, S. \& J. Streefkerk (2002). Relationships between biotic and abiotic conditions. Conservation and restoration of raised bogs, Dept. of the Environment and Local Government; Staatsbosbeheer: 186-209.

Waddington, J. M., Kellner, E., Strack, M., \& Price, J. S. (2010). Differential peat deformation, compressibility, and water storage between peatland microforms: Implications for ecosystem function and development. Water Resources Research, 46, W07538. https://doi.org/ 10.1029/2009WR008802

Walsh, S. (2012). A summary of climate averages for Ireland 1981-2010. Met Eireann: Dublin.

Whittington, P., \& Price, J. (2012). Effect of mine dewatering on peatlands of the James Bay Lowland: The role of bioherms. Hydrological Processes, 26(12), 1818-1826. https://doi.org/10.1002/hyp.9266

Wösten, J. H. M., Ismail, A. B., \& van Wijk, A. L. M. (1997). Peat subsidence and its practical implications: A case study in Malaysia. Geoderma, 78(1-2), 25-36. https://doi.org/10.1016/S0016-7061(97)00013-X

Young, D. M., Baird, A. J., Morris, P. J., \& Holden, J. (2017). Simulating the long-term impacts of drainage and restoration on the ecohydrology of peatlands. Water Resources Research, 53, 6510-6522. https://doi.org/10.1002/2016WR019898 
Yu, Z., Beilman, D. W., Frolking, S., MacDonald, G. M., Roulet, N. T., Camill, P., \& Charman, D. J. (2011). Peatlands and their role in the global carbon cycle. Eos, Transactions American Geophysical Union, 92(12), 97-98. https://doi.org/10.1029/2011EO120001

Zanello, F., Teatini, P., Putti, M., \& Gambolati, G. (2011). Long term peatland subsidence: Experimental study and modeling scenarios in the Venice coastland. Journal of Geophysical Research, 116, F04002. https://doi.org/10.1029/2011JF002010 